\title{
An on-farm study of the herbage quality and sward characteristics of plantain-clover mixes during late summer and autumn and resulting lamb growth rates
}

\author{
L.M. CRANSTON, P.D. KEMP, S.T. MORRIS and B.A. WOOD \\ School of Agriculture and Environment, Massey University, \\ Private Bag,11222, Palmerston North, New Zealand
}

1.cranston@massey.ac.nz

\begin{abstract}
An on-farm study investigated the herbage quality and sward characteristics of plantain-clover mixes and resulting lamb growth rates during late summer and autumn. Three farms were chosen, each with a minimum of 10 ha of plantain-clover mix (Plantago lanceolata 'Ceres Tonic', Trifolium pratense, Trifolium repens) used for lamb finishing. Each farm managed the plantain-clover mix area using their routine management without advice or comment from research staff. Throughout autumn, at approximately monthly intervals on the three farms, the pre- and post-grazing herbage masses, botanical composition, herbage quality, plantain dry matter content, secondary chemical composition and lamb growth rates were monitored. A low percentage of clover in the sward, a high percentage of dead stem material and a low crude protein concentration in plantain during dry periods, were identified as the most likely causes of low lamb liveweight gains during autumn. Grazing management during spring that maintains control of plantain stems and encourages the presence of clover, appears to be a key management technique for ensuring high lamb liveweight gains on plantain-clover mixes in late summer and autumn.
\end{abstract}

Keywords: Plantago lanceolata, dry matter, crude protein, metabolisable energy, secondary compounds

\section{Introduction}

Some farmers are using plantain (Plantago lanceolata) and white (Trifolium repens) and red clover (Trifolium pratense) mixes to increase the amount of high quality forage grown during summer and autumn. Research has shown plantain-clover mixes can increase the growth rates of lambs and young cattle during summer and autumn compared to grass-based swards (Pettigrew et al. 2016; Somasiri et al. 2015a,b). However, these research trials used optimal grazing management to provide high quality, unrestricted feed $(\geq 7 \mathrm{~cm}$ postgrazing height). In contrast to other seasons, many farmers report disappointing livestock performance when grazing plantain-clover mixes during autumn. This indicates that there may be a mismatch between grazing management and the characteristics (composition or quality) of plantain-clover mixes on commercial farms, compared to that on research farms.

Previous studies have shown the crude protein concentration of plantain can be low $(<15 \%)$ during autumn (Lee et al. 2015; Pain et al. 2015), potentially limiting the metabolisable protein supply to livestock, thereby limiting livestock performance (Brookes \& Nicol 2007). However, the protein concentration in plantain-clover mixes is unlikely to be limiting due to the normally high protein concentration in clover (Ulyatt et al. 1976). Nevertheless, if the percentage of clover in the sward is low it is possible that both the protein and metabolisable energy content of the sward may limit lamb liveweight gain. Also, on-farm lamb dry matter intakes may be restricted by grazing to low residuals, as best practice post-grazing sward height of plantain-clover mixes is higher than that of grass-based swards (Cranston et al. 2015a). Anecdotal evidence also suggests the dry matter percentage of plantain may be particularly low under certain environmental conditions (e.g. low soil moisture), thereby limiting animal dry matter intake. Furthermore, the concentration of secondary compounds in plantain peaks during autumn (Navarrete et al. 2016; Tamura \& Nishibe 2002) and at high concentrations, these compounds have been hypothesised to reduce the palatability of plantain.

It is likely that one or several of these attributes may result in lower than expected lamb growth. The aim of this study was to monitor the pre- and post-grazing herbage masses, botanical composition and herbage quality parameters of plantain-clover mixes on three commercial farms throughout late-summer and autumn, and to use these data to explain observed differences in lamb liveweight gain over these seasons.

\section{Methods}

An on-farm investigation on the use of plantain-clover mixes for lamb growth was undertaken between February and May 2017 on three commercial farms, with the approval of the Massey University Animal Ethics Committee. Two farms were located in the Wairarapa (Farm 1 and Farm 2) and a third was located in the Manawatu (Farm 3). Each farm contained an area 
of at least 10 hectares of plantain-clover mix (Plantago lanceolata 'Ceres Tonic', Trifolium pratense, Trifolium repens) which was established in the previous 0.5-2 years and was used for rotationally grazing lambs. On Farm 1, lambs were shifted to a new paddock every 4-5 days, completing a rotation every 20-25 days. On Farm 2, lambs were shifted to a new paddock every 5-7 days, completing a rotation every 15-21 days. On Farm 3, lambs were shifted to a new paddock every 2-3 days, completing a rotation every 16 days. Lamb numbers were adjusted based on herbage availability (Table 1). Each farmer managed the plantain-clover mix area using their routine management without advice or comment from research staff.

Table 1 Pre- and post-grazing herbage mass and sward height, dry matter percentage of plantain, percentage of live leaf, dead stem and clover in the sward, and the number and growth rates ( $\mathrm{g} /$ day) of lambs throughout autumn on the three farms. Values are presented as mean \pm standard error of the mean.

\begin{tabular}{lcccc}
\hline & February & March & April & May \\
\hline Farm 1 & & & \\
Pre-grazing herbage mass (kg DM/ha) & $2580 \pm 218$ & - & - & $2350 \pm 218$ \\
Post-grazing herbage mass (kg DM/ha) & $1888 \pm 218$ & $1507 \pm 218$ & - & $1320 \pm 218$ \\
Pre-grazing sward height (cm) & $10.3 \pm 0.93$ & - & - & $13.1 \pm 0.93$ \\
Post-grazing sward height (cm) & $6.9 \pm 0.93$ & $14.5 \pm 0.93$ & - & $9.3 \pm 0.93$ \\
DM\% & $23.5 \pm 0.49$ & $11.4 \pm 0.49$ & - & $11.8 \pm 0.49$ \\
Live leaf (\% of DM) & $88.3 \pm 4.4$ & $81.1 \pm 4.4$ & - & $1.1 \pm 4.4 \pm 4.4$ \\
Dead stem (\% of DM) & $3.4 \pm 4.4$ & $8.2 \pm 4.4$ & - & $10.9 \pm 4.4$ \\
Clover (\% of DM) & $4.1 \pm 4.4$ & 69 & - & $12.5 \pm 4.4$ \\
Number of lambs & 96 & $243 \pm 1$ & 66 \\
Lamb growth rate (g/day) & $255 \pm 9$ & $\dagger$ & $205 \pm 10$ \\
\hline
\end{tabular}

\section{Farm 2}

Pre-grazing herbage mass (kg DM/ha)

Post-grazing herbage mass (kg DM/ha)

$2845 \pm 226$

Pre-grazing sward height $(\mathrm{cm})$

Post-grazing sward height $(\mathrm{cm})$

$\mathrm{DM} \%$

Live leaf (\% of DM)

Dead stem (\% of DM)

Clover (\% of DM)

Number of lambs

Lamb growth rate (g/day)

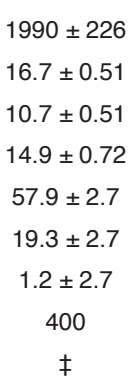

$\ddagger$

-
$1645 \pm 226$
-
$9.3 \pm 0.51$
$13.7 \pm 0.72$
$43.7 \pm 2.7$
$34.2 \pm 2.7$
$1.7 \pm 2.7$
400
$\ddagger$

$\ddagger$

$\begin{array}{cc}1780 \pm 226 & 2625 \pm 226 \\ 1472 \pm 226 & 1558 \pm 226 \\ 16.5 \pm 0.51 & 14.9 \pm 0.51 \\ 11.7 \pm 0.51 & 9.1 \pm 0.51 \\ 10.3 \pm 0.72 & 10.6 \pm 0.72 \\ 58.1 \pm 2.7 & 89.1 \pm 2.7 \\ 20.2 \pm 2.7 & 2.9 \pm 2.7 \\ 4.1 \pm 2.7 & 2.9 \pm 2.7 \\ 202 & 105 \\ -107 \pm 6 & 151 \pm 10\end{array}$

$\begin{array}{cccc}2515 \pm 150 & 1537 \pm 150 & 1667 \pm 150 & - \\ 2677 \pm 150 & 1295 \pm 150 & 1225 \pm 150 & 1052 \pm 150 \\ 18.1 \pm 0.89 & 10.9 \pm 0.89 & 15.1 \pm 0.89 & - \\ 11.8 \pm 0.89 & 7.7 \pm 0.89 & 9.6 \pm 0.89 & 10.7 \pm 0.89 \\ 14.2 \pm 0.68 & 9.7 \pm 0.68 & 9.9 \pm 0.68 & 13.3 \pm 0.68 \\ 54.9 \pm 2.2 & 50.5 \pm 2.2 & 38.5 \pm 2.2 & 84.3 \pm 2.2 \\ 5.2 \pm 2.2 & 7.2 \pm 2.2 & 21.7 \pm 2.2 & 0 \pm 2.2 \\ 19.1 \pm 2.2 & 34.6 \pm 2.2 & 22.5 \pm 2.2 & 13.6 \pm 2.2 \\ 800 & 800 & 800 & 800 \\ 261 & 261 & \S & \S\end{array}$

\section{Farm 3}

Pre-grazing herbage mass (kg DM/ha)

Post-grazing herbage mass (kg DM/ha)

Pre-grazing sward height $(\mathrm{cm})$

Post-grazing sward height $(\mathrm{cm})$

DM\%

Live leaf (\% of DM)

Dead stem (\% of DM)

Clover (\% of DM)

Number of lambs

Lamb growth rate (g/day)

† The plantain-clover mix was used for breeding ewes during this month.

$\ddagger$ Lambs began grazing the plantain-clover mix in mid-February but were removed on 10 March as they were losing weight.

$\S$ Lambs were not growing as fast as February/March period but were still noted to be growing faster than lambs of a similar weight grazing a grass-clover mix. 


\section{Herbage measurements}

All measurements and herbage samples were collected every 3-4 weeks from each farm. Sampling dates were timed to coincide with the weighing of lambs and the movement of lambs to a fresh paddock, so that accurate pre- and post-grazing samples could be obtained. Herbage mass was measured pre- and postgrazing by cutting four $0.1 \mathrm{~m}^{2}$ quadrats (Frame 1993) at ground level with an electric shearing hand-piece. These samples were washed and oven-dried for at least $24 \mathrm{~h}\left(\right.$ at $\left.70^{\circ} \mathrm{C}\right)$ to a constant weight. Sward height was measured by taking two replicates of 50 measurements using a sward stick, both pre- and post-grazing. Four herbage samples for botanical composition were randomly collected within a pre-grazing paddock by cutting a $1 \mathrm{~m} \times 0.1 \mathrm{~m}$ wide strip to ground level with an electric shearing hand-piece. The samples were then separated into plant parts (live plantain leaf, live plantain stem, dead plantain leaf, dead plantain stem and all clover) and each plant part was oven-dried (at $70^{\circ} \mathrm{C}$ ) to a constant weight. Botanical composition was calculated on a dry weight basis. Plantain DM\% was calculated from weighing four samples of pure plantain ( $\sim 100 \mathrm{~g}$ wet weight) and then again after drying for 48 h at $70^{\circ} \mathrm{C}$.

Herbage quality was assessed by collecting three pluck samples (Frame 1993) of pure plantain and of the mixed sward from a paddock before grazing. Pluck samples of dead plantain stem were also collected and assessed from Farm 2. The samples were freezedried, ground to pass a $1-\mathrm{mm}$ sieve and analysed for in vitro dry organic matter digestibility (DOMD) (Roughan \& Holland 1977), crude protein (CP) (total combustion method), and neutral detergent fibre (NDF) (Robertson \& Van Soest 1981). Metabolisable energy (ME) was calculated as DOMD $\times 0.163$ according to Roughan \& Holland (1977). The pure plantain samples were also analysed using high-performance liquid chromatography (HPLC) to determine the concentration of the secondary compounds catalpol, aucubin, and acteoside, using the methods of Navarrete et al. (2016).

\section{Animal measurements}

Individual unfasted lamb liveweights were collected at approximately 3-week intervals from Farm 1 and Farm 2, and an average mob liveweight was collected sporadically from Farm 3.

\section{Statistical analyses}

All data were analysed using SAS (Statistical Analysis System, Version 9.3). Herbage quality traits were each analysed separately for each farm in a mixed model including the fixed effects of plant type (pure plantain versus mixed sward sample or plantain live material versus dead stem) and sampling date. Herbage mass and dry matter percentage were analysed with the fixed effect of sampling date. Herbage data are presented as mean \pm standard error of the mean (SEM). All significances were judged and expressed in the Results and Discussion sections at $\mathrm{P}<0.05$. Descriptive statistics (mean and SEM) were calculated for lamb liveweight gain at each time point.

\section{Results and Discussion \\ Pre- and post-grazing herbage masses}

Minimum post-grazing herbage mass and sward height were always greater than $1200 \mathrm{~kg} \mathrm{DM} / \mathrm{ha}$ and $6.9 \mathrm{~cm}$, respectively, with the exception of the observed postgrazing herbage mass $(1052 \pm 150 \mathrm{~kg} \mathrm{DM} / \mathrm{ha})$ in May at Farm 3 (Table 1). The lowest post-grazing herbage mass was observed in May on all farms, aligning with the end of the grazing season. Somasiri et al. (2015a) suggested that lambs can consume ad libitum intakes of herb-based swards provided that sward height is maintained at $7 \mathrm{~cm}$ or above. This suggests that lamb feed intake was not restricted during the autumn observation period, on all the farms in this study.

\section{Plantain content (DM \%)}

The dry matter content of plantain was highest during February on all three farms (Table 1). At Farm 2 the dry matter content was $\sim 10 \%$ during April and May, while at Farm 3, the dry matter content was $<10 \%$ during March and April. Anecdotal evidence proposes that a forage with a low dry matter content $(10 \%)$ can result in reduced dry matter intakes as animals are likely to feel sated faster due to the large volume of water consumed. However, there is little scientific literature to support this argument (Allison 1985) and animals are more likely to increase urinary output to enable greater intake of wet feed, without reducing their total dry matter intake.

\section{Botanical composition (\% of DM)}

There were large differences in the botanical composition of the plantain-clover swards across the three farms and throughout autumn. Most notably, the percentage of clover in the swards varied greatly with Farm 1 containing 4-13\% clover, Farm 2 1-4\% clover and Farm 3 14-35\% clover (Table 1). One of the advantages of plantain-based swards is their erect growth habit allowing more clover in the sward relative to the denser grass-based swards, where clover growth can be restricted (Somasiri et al. 2015a). Previous research has shown lambs can grow at $>220 \mathrm{~g}$ /day in late summer and $>250 \mathrm{~g} /$ day during autumn on plantainclover mixes (Somasiri et al. 2015a,b). However, in these studies the sward consistently contained 20$40 \%$ clover, and it was hypothesised that the lamb 

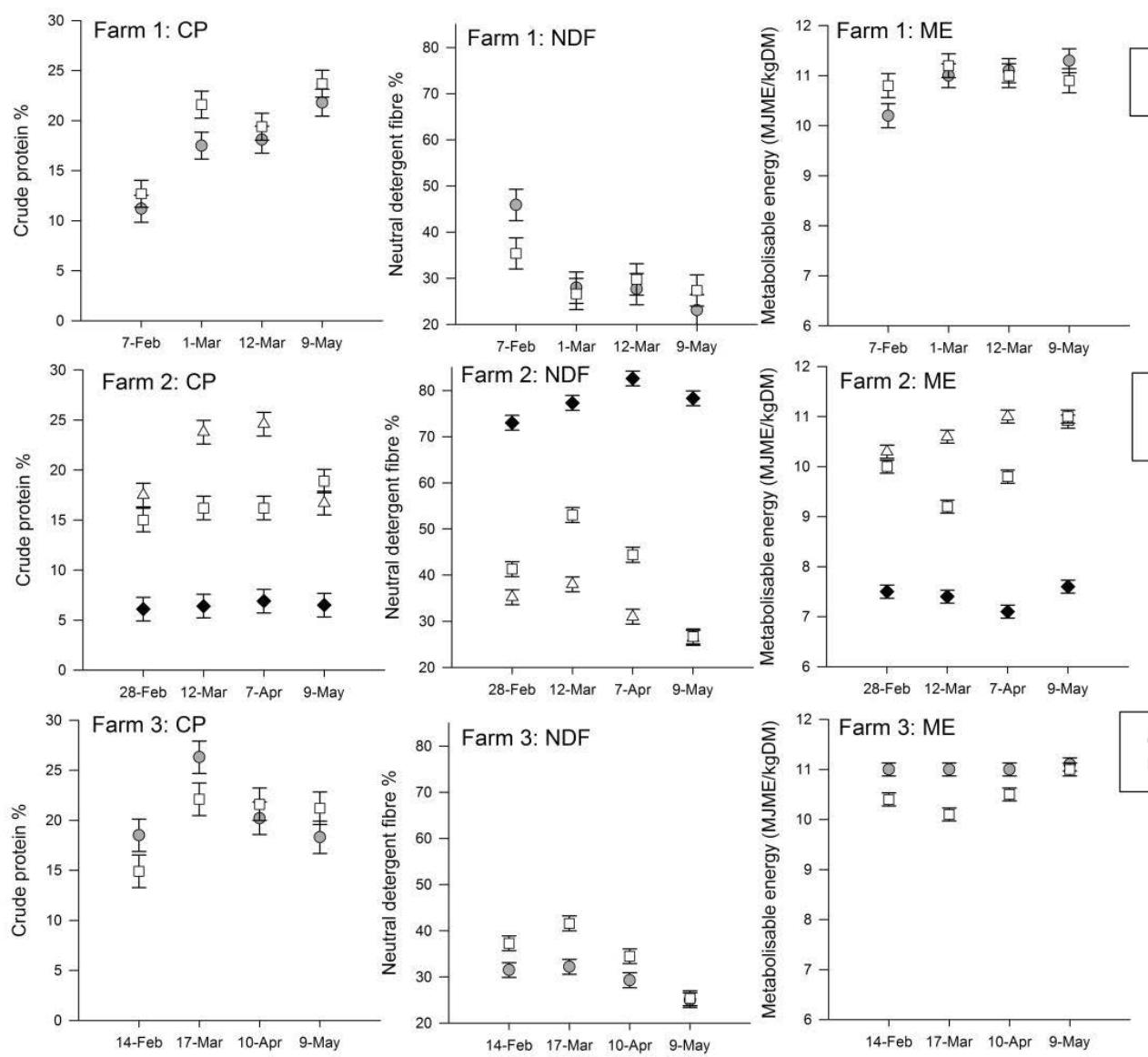

Figure 1 The crude protein \% (CP), neutral detergent fibre \% (NDF) and metabolisable energy content (ME) of herbage samples (Farm 1 and Farm 3: pure plantain, mixed plantain-clover; Farm 2: live plantain, dead plantain stem, mixed plantainclover) throughout autumn on the three farms. Error bars represent standard error of the mean.

performance was driven by the high percentage of clover in the sward. In the present study, the lamb growth rates appeared to reflect the percentage of clover in the swards across the farms. Given that all three farms used a similar sowing rate it is likely that either grazing management or the environment affected the sward composition. Previous research has demonstrated that if plantain-clover swards are consistently hard-grazed, this can lead to a plantain dominant sward (Cranston et al. 2015b). Furthermore, Kemp et al. (2014) observed variable lamb growth rates on pure swards of plantain during late-summer/early-autumn, and suggested lamb growth rates will only exceed $200 \mathrm{~g}$ /day when plantain is in a green leafy state along with consistent rainfall and a post-grazing sward height no lower than $5 \mathrm{~cm}$. Moreover, plantain-clover swards with a considerable amount of clover will fix more nitrogen and, therefore, allow the plantain to thrive.

The percentage of dead stem (containing $\sim 7 \% \mathrm{CP}$, $80 \% \mathrm{NDF}$ and $7 \mathrm{MJ} \mathrm{ME}$, Figure 1) in the swards varied between the farms. Farm 2 had a large amount of dead stem $(>20 \%$ of DM) throughout February, March and April, and it was only reduced to minimal levels in May (Table 1). Between February and April lambs grazing the plantain-clover sward at Farm 2 consistently lost weight, however, once the dead stem was removed and the sward was mainly live leaf ( $89 \%$ of DM), reasonable lamb growth rates $(151 \mathrm{~g} /$ day $)$ were observed during May. At Farm 1 the percentage of dead stem was low $(<4 \%)$ throughout February and March and increased to $10.9 \%$ in May, reflecting a decrease in lamb growth rates. At Farm 3, the percentage of dead stem peaked during April (22\%), at which point cattle co-grazed the plantain sward and the stem material was removed before the next sampling date. Lambs are known to avoid grazing plantain stem (Pain et al. 2015) and thus reduced liveweight gains are likely when a plantainclover sward contains a substantial proportion of stem $(>20 \%)$. Alternately, if lambs are left to graze the low quality stem, they will also have poor liveweight gains. 
Overall the results indicated that management might be critical in both preventing and removing the build-up of stem material.

\section{Crude protein (CP), neutral detergent fibre (NDF) and metabolisable energy (ME) content}

The $\mathrm{CP}$ content of plantain was lowest $(\mathrm{P}<0.05)$ during February on all three farms (Figure 1). Growing animals need to be offered a sward with a minimum CP content of $15 \%$ to maximise growth rates (Rattray et al. 2007). Thus, it is possible that lamb growth rates would have been restricted on all of the farms during February. Previous studies have also observed the $\mathrm{CP}$ content of plantain can be limiting during autumn (Lee et al. 2015; Pain et al. 2015). All three farms had received adequate rainfall in mid-late February $(70 \mathrm{~mm}$ at Farm 1 and Farm 2, 35ml at Farm 3), and the CP content of plantain was greater $(\mathrm{P}<0.05)$ at the next sampling date in March. Kemp et al. (2014) also observed the CP content of plantain spiked following rainfall in a dry summer. Many farmers apply nitrogen fertiliser during autumn to increase herbage production and quality. Farm 2 applied $40 \mathrm{~kg} \mathrm{~N} / \mathrm{ha}$ on $21 \mathrm{March}$, but there was no $(\mathrm{P}>0.05)$ observed increase in the $\mathrm{CP}$ content of plantain, contrary to the suggestion of Kemp et al. (2014). However, it may be less effective if applied during autumn, as demonstrated on Farm 2.

It was hypothesised that the contribution of clover in a mixed plantain-clover sward would result in a higher average sward $\mathrm{CP}$ and $\mathrm{ME}$ content than for plantain alone (Cranston et al. 2015a). However, this was not the case for either Farm 2 or Farm 3. Rather, on Farm 3, the pure plantain samples contained a greater $(\mathrm{P}<0.05)$ $\mathrm{CP}$ content than mixed samples during February and March, and did not differ $(\mathrm{P}>0.05)$ from mixed samples during April and May. Similarly, pure plantain samples contained a greater $(\mathrm{P}<0.05) \mathrm{ME}$ content than mixed samples in all months except May. The lower ME content in the mixed swards may have been due to the large amount of red clover stem present at Farm 3. On Farm 2, in general, the $\mathrm{CP}$ and ME content did not differ $(\mathrm{P}>0.05)$ between pure plantain samples and mixed samples, except pure plantain samples had lower $(\mathrm{P}<0.05) \mathrm{ME}$ content in early February and lower $(\mathrm{P}<0.05) \mathrm{CP}$ content in late February. Combined, these results emphasised that plantain in a green leafy state during autumn has a ME content between 10-11 MJ $\mathrm{ME}$, and is therefore capable of supporting medium to high rates of liveweight gain. However, the overall sward ME content may be lower if there is a high proportion of stem or dead material in the sward.

\section{Secondary compounds}

The concentrations of secondary compounds catapol, aucubin and acteoside in 'Ceres Tonic' plantain were low across all three farms and did not appear to peak in late autumn, contrasting with previous evidence (Tamura \& Nishibe 2002; Navarrete et al. 2016). At Farm 1, the plantain sward contained $0.07-0.24 \mathrm{mg} / \mathrm{g}$ DM catapol, 1.86-5.23 mg/g DM aucubin and 1.15$2.82 \mathrm{mg} / \mathrm{g}$ DM acteoside. At Farm 2, the plantain sward contained 0.01-0.08 mg/g DM catapol, 0.67-2.80 $\mathrm{mg} / \mathrm{g} \mathrm{DM}$ aucubin and $0.50-1.15 \mathrm{mg} / \mathrm{g}$ DM acteoside, while at Farm 3, the plantain sward contained 0.001$0.15 \mathrm{mg} / \mathrm{g}$ DM catapol, $1.31-2.40 \mathrm{mg} / \mathrm{g}$ DM aucubin and $1.24-3.15 \mathrm{mg} / \mathrm{g}$ DM acteoside. Furthermore, there was no apparent effect of secondary compounds on the observed lamb growth rates. Previous anecdotal evidence has suggested that high concentrations of secondary compounds could negatively affect palatability, however, the observed concentrations were sufficiently low that this would have been unlikely.

\section{Conclusion}

A low percentage of clover in the sward, a high percentage of dead plantain stem and a low crude protein content in plantain during dry periods, were identified as the most likely causes of low lamb liveweight gains during summer and autumn. Grazing management that maintains control of plantain stem growth during spring and encourages the presence of clover, appears to be a key management technique for ensuring high lamb liveweight gains on plantain-clover mixes in summer and autumn.

\section{ACKNOWLEDGEMENTS}

We are indebted to Katie Alslop from Omahu Farm, Ian Evans from Mangarata, Taratahi and Ian Brown from Cheltenham Downs, Landcorp for allowing us to collect lamb growth and herbage data from their farms. We thank the farmers involved in the Sustainable Farming Fund perennial summer forage farmer learning group (SFF 408095) for their assistance in developing this research idea. Catriona Jenkinson is thanked for her technical assistance.

\section{REFERENCES}

Allison, C.D. 1985. Factors affecting forage intake by range ruminants: A review. Journal of Range Management 38: 305-311.

Brookes, I.M.; Nicol, A.M. 2007. The protein requirements of grazing livestock. In: Pasture and supplements for grazing animals. Eds. Rattray, P.V.; Brookes, I.M.; Nicol, A.M. New Zealand Society of Animal Production, Hamilton, New Zealand.

Cranston, L.M.; Kenyon, P.R.; Morris, S.T.; Kemp, P.D. 2015a. A review of the use of chicory, plantain, red clover and white clover in a sward mix for increased sheep and beef production. Journal of New Zealand Grasslands 77: 89-94. 
Cranston, L.M.; Kenyon, P.R.; Morris, S.T.; LopezVillalobos, N.; Kemp, P.D. 2015b. Effect of postgrazing height on the productivity, population and morphology of a herb and legume mix. New Zealand Journal of Agricultural Research 58: 397-411.

Frame, J. 1993. Herbage Mass. pp. 39-69. In: Sward measurement handbook. Eds. Hodgson, J.; Baker, R.D.; Davies, D.A.; Laidlaw, A.S.; Leaver, J.D. British Grassland Society, Reading, United Kingdom.

Kemp, P.D.; Kenyon, P.R.; Morris, S.T.; Johnston, T.; Appleton, H.; Best, H.K. 2014. Summer lamb production and grazing management of pure swards of plantain (Plantago lanceolata). Proceedings of the New Zealand Society of Animal Production 74: 94101.

Lee, J.M.; Hemmingson, N.R.; Minneé, E.K.; Clark, C.E.F. 2015. Management strategies for chicory (Cichorium intybus L.) and plantain (Plantago lanceolata L.): Impact on dry matter yield, nutritive characteristics and plant density. Crop and Pasture Science 66: 168-183.

Navarrete, S.; Kemp, P.D.; Pain, S.J.; Back, P.J. 2016. Bioactive compounds, aucubin and acteoside, in plantain (Plantago lanceolata L.) and their effect on in vitro rumen fermentation. Animal Feed Science and Technology 222: 158-167.

Pain, S.J.; Corkran, J.R.; Kenyon, P.R.; Morris, S.T.; Kemp, P.D. 2015. The influence of season on lambs' feeding preference for plantain, chicory and red clover. Animal Production Science 55: 1241-1249.

Pettigrew, E.J.; Morris, S.T.; Back, P.J.; Kenyon, P.R.; Berry, J.; Donald, A.J.; Lane, A.L.; Hickson, R.E. 2016. Growth of weaned Friesian bull calves on a herb sward or with concentrate supplementation during late summer and early autumn. New Zealand Journal of Agricultural Research 59: 1-10.

Rattray, P.V.; Brookes, I.M.; Nicol, A.M. 2007. Pasture and Supplements for Grazing Animals. New Zealand Society of Animal Production, Hamilton, New Zealand.

Robertson, J.B.; Van Soest, P.J. 1981. The detergent system of analysis and its application to human foods. pp. 123-158. In: The analysis of dietary fibre in food, Vol. 3. Eds. James, W.P.T.; Theander, O. Marcel Dekker Inc., New York, USA.

Roughan, P.G.; Holland, R. 1977. Predicting in- vivo digestibilities of herbages by exhaustive enzymic hydrolysis of cell walls. Journal of the Science of Food and Agriculture 28: 1057-1064.

Somasiri, S.C.; Kenyon, P.R.; Kemp, P.D.; Morel, P.C.H.; Morris, S.T. 2015a. Growth performance and carcass characteristics of lambs grazing forage mixes inclusive of plantain (Plantago lanceolata L.) and chicory (Cichorium intybus L.). Small Ruminant Research 127: 20-27.

Somasiri, S.C.; Kenyon, P.R.; Morel, P.C.H.; Kemp, P.D.; Morris, S.T. 2015b. Herb-clover mixes increase lamb live weight gain and carcass weight in the autumn period. New Zealand Journal of Agricultural Research 58: 384-396.

Tamura, Y.; Nishibe, S. 2002. Changes in the concentrations of bioactive compounds in plantain leaves. Journal of Agricultural and Food Chemistry 50: 2514-2518.

Ulyatt, M.J.; Lancashire, J.A; Jones, W.T. 1976. The nutritive value of legumes. Proceedings of the New Zealand Grassland Association 38: 107-117. 